lesion appearance. This result shows that lesion formation was inhibited by the treatment for 1 to 3 hours, but not by treatment for 10 minutes. Lesion size became smaller by the longer treatment on kinetin solution. It is suggested that kinetin, in the case of TMV-RNA inoculation, may act on relatively later infection stages, but not on early infection process.

These findings suggest that kinetin may act not only on the early infection process of TMV, but also on its multiplication, although the mode of inhibitory effect of kinetin is different in the case of TMV-RNA inoculation.

(Received April 17, 1971)

日植病報 $37: 309-311(1971)$

Ann. Phytopath. Soc. Japan 37 : 309-311 (1971)

暗所で育てたオオムギ葉内でのオオムギ斑葉モザイクウイルスの 増殖とこれに光をあてたときの stripe 病徴の出現

$$
\text { 山口昭* · 大羽康 利* }
$$

\footnotetext{
Akira Yamaguchi* and Yasutoshi Онва* : Multiplication of Barley Stripe Mosaic Virus within Etiolated Barley Leaves and the Appearance of Stripe Mosaic Symptoms after Exposure to Light
}

ウイルスによる mosaic, mottle, stripe などの葉 の病徵は, 葉緑体の形成過程に起こる部分的異常によ るものと考えられている。このことは, 葉緑体が発達 し終った成熟葉には，これらの病幑が現われないこと からも推定できる。しかしながら, 病徵出現の詳細に ついてはまだ調べられていない。

本実験では，暗黑下で育てた植物にウイルスを接種 し, ウイルス増殖の過程で光をあてて緑化し, 葉に緑 色濃淡の病徵が現われる様子を調べることにした。こ の種の実験には, 双子葉よりも単子葉植物が好適であ ると考光, オオムギ斑葉モザイクウイルス（barley stripe mosaic virus, BSMV) とオオムギ（Hordeum vulgare L.) の組合せを用いた。をず，暗黒下でウイ ルスが増殖することを確かめ, ついで, 光にあてたと きの stripe 病徴の現われ方を観察した。

BSMV を分与された岡山大学農業生物研究所井上 忠男博士, オオムギ種子を分譲して下さった愛知県農 業総合試験場作物研究所に厚くお゙礼申し上げる。

\section{暗処理オオムギ葉内でのオオムギ 斑葉モザイクウイルスの增殖}

オオムギの種子（品種横綱および劍吉 3 号）を 2 日 間催芽したのち, バーミキュライトを入れたプラス チックカップ（径 $10 \mathrm{~cm}$, 深さ $5 \mathrm{~cm}$ ) に播種する。こ のカップには，はじめ Knop 氏液を与えておき，あと は毎日灌水した。 $25^{\circ} \mathrm{C}$, 完全暗黒下で育てた。播種 5 日後には第 1 葉は十分展開し，このとき第 2 葉は見え るが展開していない。この第 1 葉に BSMVを摩擦接 種する。接種源には BSMV 䍜病オオムギ葉を磨砕し た粗汁液を用いた。水洗後, さらに 6 日間暗所に置 き，接種した第 1 葉とあとから展開した第 2 葉とに分 けて収穫した。生体重当り約 2 倍のりん酸 buffer で 磨砕した汁液を，あらかじめ明条件下で育てたオオム ギ (横綱) の苗に接種し, stripe 病徵を示すかどう かによって, 暗黒下で接種したオオムギ葉中で BSMV が増殖したかどらかを判定した。結果を第 1 表に示し た。この結果から， BSMVは, 播種時から暗黒下で 生育した黄化葉 (etiolated leaves) 中で増殖するこ とが明らかである。用いた検定植物が全身感染宿主で

* 名古屋大学農学部 Faculty of Agriculture, Nagoya University, Chikusa-ku, Nagoya, Japan. 
Table 1. Multiplication of barley stripe mosaic virus within etiolated barley leaves (Hordeum vulgare L. vars. Yokozuna and Kenyoshi No. 3) grown in complete darkness

\begin{tabular}{|c|c|c|c|c|}
\hline \multirow{3}{*}{$\begin{array}{l}\text { Days after } \\
\text { inoculation }\end{array}$} & \multicolumn{3}{|c|}{ Inoculum } & \multirow{3}{*}{$\begin{array}{l}\text { Control } \\
\left(\begin{array}{c}\text { Purified } \\
\text { BSMV }\end{array}\right)\end{array}$} \\
\hline & \multirow{2}{*}{$\begin{array}{c}\text { Yokozuna } \\
\begin{array}{c}\text { Inoculated } \\
1 \text { st leaf }\end{array}\end{array}$} & \multicolumn{2}{|c|}{ Kenyoshi No. 3} & \\
\hline & & $\begin{array}{l}\text { Inoculated } \\
1 \text { st leaf }\end{array}$ & $2 \mathrm{nd}$ leaf & \\
\hline 4 & $10 / 18^{a)}$ & $3 / 13$ & $5 / 9$ & $2 / 6$ \\
\hline 5 & $18 / 21$ & $10 / 16$ & $9 / 11$ & $4 / 7$ \\
\hline 6 & $18 / 22$ & $13 / 20$ & $9 / 11$ & $5 / 10$ \\
\hline 7 & $22 / 22$ & $21 / 22$ & $11 / 11$ & $8 / 10$ \\
\hline
\end{tabular}

Seedlings of barley "Yokozuna" grown under light were used for bioassay.

a) Number of infected seedlings / Number of inoculated seedlings.

Table 2. The sequence of appearance of stripe mosaic symptoms in 2 nd leaf of barley seedlings (Hordeum vulgare L. var. Kenyoshi No. 3) grown in complete darkness, after exposure to light at various days after inoculation of 1 st leaf with barley stripe mosaic virus

\begin{tabular}{|c|c|c|c|c|c|c|c|c|c|c|c|c|c|c|}
\hline \multirow[b]{2}{*}{ Treatment } & \multicolumn{14}{|c|}{ Days after inoculation } \\
\hline & 1 & 2 & 3 & 4 & 5 & 6 & 7 & 8 & 9 & 10 & 11 & 12 & 13 & 14 \\
\hline $\begin{array}{l}\text { Light just after } \\
\text { inoculation }\end{array}$ & $0 / 0^{a}$ & $0 / 0$ & $1 / 3$ & $2 / 6$ & $2 / 9$ & 一 & $9 / 14$ & $9 / 15$ & $13 / 15$ & $14 / 15$ & & & & \\
\hline $\begin{array}{c}\text { Light } 2 \text { days aft } \\
\text { inoculation }\end{array}$ & & $0 / 0$ & $1 / 2$ & $1 / 5$ & $2 / 5$ & - & $13 / 14$ & $13 / 14$ & $14 / 14$ & $14 / 15$ & $15 / 15$ & & & \\
\hline $\begin{array}{l}\text { Light } 4 \text { days aft } \\
\text { inoculation }\end{array}$ & & & & $0 / 7$ & $0 / 10$ & 一 & $11 / 13$ & $11 / 14$ & $13 / 15$ & $15 / 15$ & & & & \\
\hline $\begin{array}{l}\text { Light } 7 \text { days aft } \\
\text { inoculation }\end{array}$ & & & & & & - & $0 / 14$ & $0 / 14$ & $3 / 14$ & $7 / 14$ & $13 / 14$ & $14 / 14$ & $14 / 14$ & $14 / 15$ \\
\hline Control ${ }^{\mathrm{b})}$ & $0 / 0$ & $0 / 4$ & $4 / 12$ & $7 / 14$ & $10 / 15$ & - & $15 / 15$ & & & & & & & \\
\hline
\end{tabular}

a) Number of seedlings with stripe mosaic symptoms in 2nd leaf/Number of seedlings with expanded 2nd leaf.

b) Seedlings were grown and inoculated under light.

あるため, 増殖したウイルス量を数量的に表わすこと はできないが，検定植物が示した病徵の激しさ执よび その感染率から判断して, 緑葉に劣らない程度のウイ ルス増殖が行なわれたと推定された。

従来, 斑入りタバコの白色部でウイルスが増殖する こと1)，アルビノソラマメの白色部に local necrotic lesion がでさること から，葉緑体を欠く部分でもウ イルスが増殖できると考えられてきた。しかし，これ らの例では, 同一葉の緑色部で増殖したウイルスが白 色部に移行するか，または緑色部の代謝が白色部での ウイルス合成に影響を与える可能性を否定することは
できなかった。本実験では, 植物全体が暗黒下に置か れているので, その可能性はあり得ない。したがっ て, 植物ウイルスの増殖に際し, 葉緑体はかならずし も必要ではないと考えられる。この事実は，すでに Fujisawa ら³がインゲンと TMV インゲン系統の組 合せで, 形態学的に確かめている。

\section{BSMV に感染した黄化オオムギ葉に光をあ てたときの stripe 病徵の現われ方}

完全暗黒下で育てたオオムギ葉中で BSMV が増殖 することがわかったので, ウイルスが増殖しつつある

1）長尾記明 - 日高 醇 (1967). 日植病報 $33: 98$. 2) Yamaguchi, A. (1968). Phytopath. Z. 61 : 399-400. 3) Fujisawa, I. and Matsui, C. (1969). Phytopathology 59 : 1544-1547. 

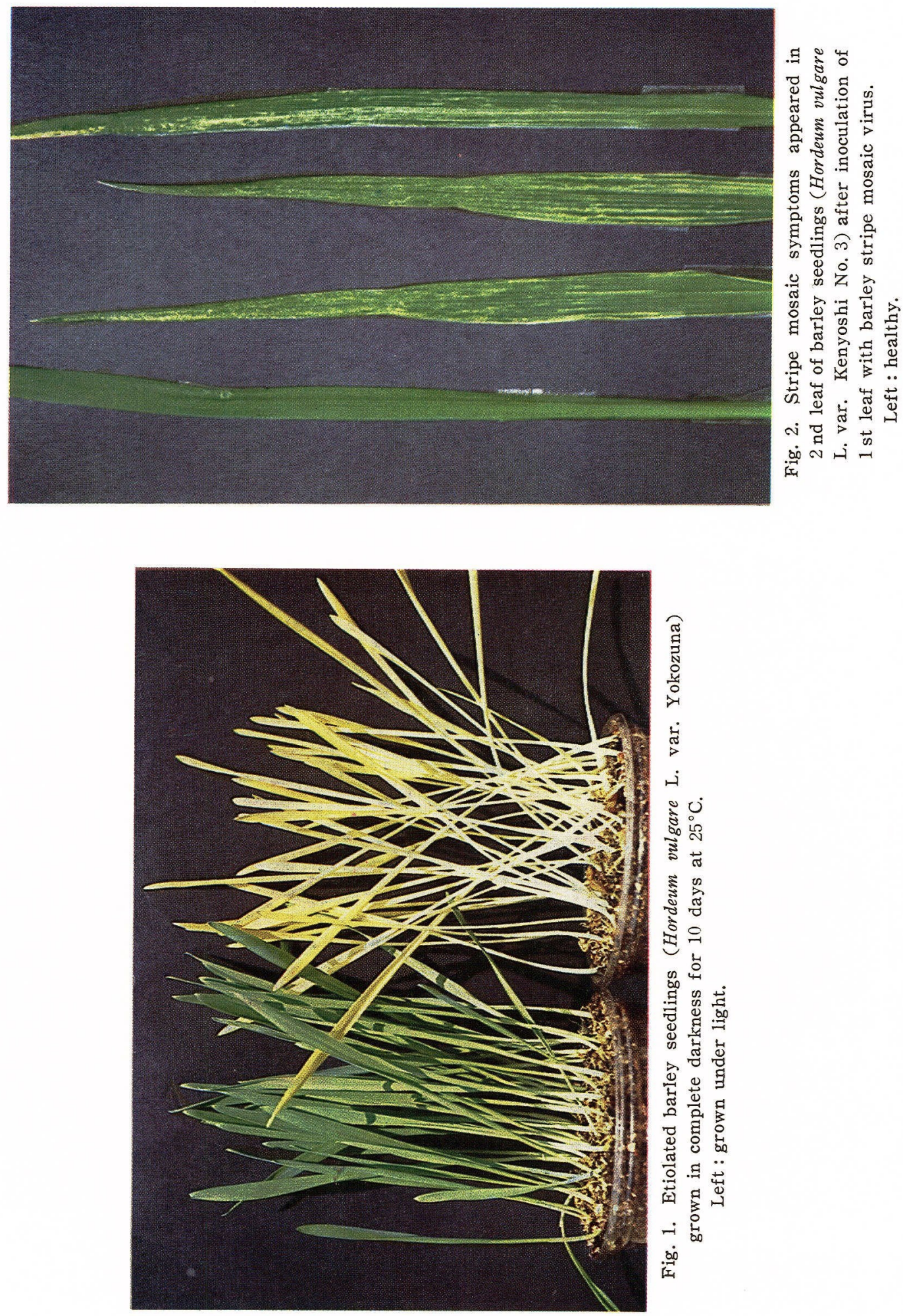
黄化葉を光にあてたとき, 第 2 葉に stripe 病徴が現 われてくる様子を観察した。

前と同じように, 1 カップ当り 15 粒ずつ播種した オオムギを, $25^{\circ} \mathrm{C}$, 暗黒下で育てる。播種後 6 日, 第 1 葉が十分展開したとき，これに BSMV を摩擦接種 した。明条件下でオオムギ第 1 葉に BSMV を接種す ると, 接種葉には病徴が現われないか, または灰白色 の大型えそ斑を生じ, 典型的な stripe 病徵は, 第 2 葉に現われるのが普通である。しかも第 2 葉にみられ るこの病徵は，第 2 葉が十分展開する前に感染しない と現われない。したがって本実験で，第 2 葉の病徵を 観察するに当って，光をあてたのちに第 2 葉がよく伸 びるものでなければならない。この点で劒吉 3 号が横 綱にまさっていたので劔吉 3 号を用いた。

接種直後から光にあてた区, 接種後 $2,4,7$ 日の それぞれの期間さらに暗所に拈いてから光にあてた区 のおの㧍のについて，第 2 葉に stripe 病徴が現われ る様子を観察してまとめたのが第 2 表である。播種直
後から暗黑で育てたオオムギ葉はクリーム色をおび た乳白色を呈している（第 1 図）。これに光をあてる と, 第 2 葉では葉基部からうす緑色に着色しはじめ, 2-3 日で全体に黄緑色を呈する。このときすでに stripe 病徵を認めることがでさる。さらに 2-3 日た つと, ますます緑色味を増し, 病徵も激しくなる。最 終的な stripe 病徵は, 明所で感染したオオムギに見 られるものと差がない（第 2 図)。光にあててから， はじめて stripe 病徵が認められるまでの日数は, 接 種後光にあてるまでの日数に関係なく，どの区でも拉 よそ3 日であった。すなわち, 黄化葉が光にあたって 緑化しはじめるのと同時に stripe 病徵を認めること がでさた。この観察事実は，黄化オオムギ葉中で BS MV が増殖する過程で, proplastid に何らかの異常 が起こって括り，光にあたって chloroplast に転化 する過程で部分的に緑化できず，その結果 stripe 病 徵を呈するにいたることを示すものと思われる。

(1971 年 4 月 6 日受理)

日植病報 $37: 311-313(1971)$

Ann. Phytopath. Soc. Japan 37 : 311-313 (1971)

\title{
Incorporation of Tritiated Phenylalanine into Lignified Cell Walls of Japanese Radish Root Infected by Peronospora parasitica*
}

\author{
Yasuji AsadA** and Takeshi KugoH**

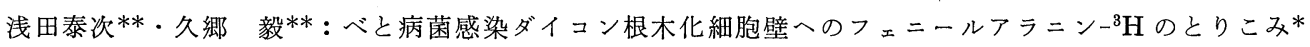

Brown and Neish ${ }^{1)}$ showed that lignin was synthesized from phenylalanine and related aromatic monomers. Radiotracers have been used to study lignin biosynthesis in higher plants ${ }^{2}$. We reported that lignin was formed only in the parenchyma cell walls of downy mildew-infected Japanese radish root as a result of the host-parasite interaction ${ }^{3}$. By microspectrophotometry, we found that greater accumulation of lignin occurred in the middle lamella of the parenchyma cell walls of Peronospora-infected Japanese radish root than that of the noninfected ones ${ }^{4}$.

* This paper constitutes Part 5 of a series of papers on the lignin formation in fungus-infected plants. Contribution No. 9.

** College of Agriculture, Ehime University, Matsuyama, Japan. 愛媛大学農学部

1) Brown, S. A. and Neish, A.C. (1955). Can. J. Biochem. Physiol. 33 : 948-962. 2) Neish, A. C. (1968). In Constitution and Biosynthesis of Lignin. (Freudenberg, K. and Neish, A.C. eds.) Springer-Verlag, Berlin, Heidelberg, New York. pp. 1-43. 3) Asada, Y. and Matsumoto, I. (1969). Ann. Phytopath. Soc. Japan $35:$ 160-167. 4) Asada, Y. and Matsumoto, I. (1971). Physiol. Plant Pathol. (in press) 